\title{
BODY MASS INDEX AND INSULIN RESISTANCE AS INDEPENDENT PREDICTORS OF HYPERTENSION IN POSTMENOPAUSAL WOMEN
}

\section{INDEKS TELESNE MASE I INSULINSKA REZISTENCIJA KAO NEZAVISNI PREDIKTORI HIPERTENZIJE KOD ŽENA U POSTMENOPAUZI}

\author{
Aleksandra Klisic (1), Verica Stanisic(2), Milovan Jovanovic (1), Nebojsa Kavaric (1), Ana Ninic (3) \\ (1) PRIMARY HEALTH CARE CENTER, PODGORICA, MONTENEGRO, (2) CLINICAL CENTER, PODGORICA, \\ MONTENEGRO, (3) DEPARTMENT OF MEDICAL BIOCHEMISTRY, UNIVERSITY OF BELGRADE - FACULTY \\ OF PHARMACY, BELGRADE, SERBIA
}

\begin{abstract}
Sažetak: Cilj: Premda su ranije studije potvrdile vezu između gojaznosti i hipertenzije, patofiziološki mehanizam ove povezanosti još uvek nije rasvetljen, naročito što postoje oprečni rezultati kada je u pitanju nezavisna uloga gojaznosti i/ili insulinske rezistencije u nastanku hipertenzije. Stoga je cilj studije bio da se ispita da li je gojaznost [merena indeksom telesne mase (ITM)] prediktor za nastanak hipertenzije, nezavisno od insulinske rezistencije [merene HOMA indeksom (HOMA-IR)] u kohorti žena u postmenopauzi. Metode: Ukupno 150 žena u postmenopauzi koje nisu na terapiji (među njima 44,7\% sa hipertenzijom) su uključene u studiju preseka. Antropometrijski i biohemijski parametri, kao i krvni pritisak su mereni. HOMA-IR je računat. Rezultati: Multivarijantna logistička regresiona analiza je pokazala da su i ITM $(\mathrm{OR}=1,240 ; \mathrm{p}=0,035)$ i HOMA-IR $(\mathrm{OR}=2,419 ; \mathrm{p}=0,008)$ nezavisni prediktori krvnog pritiska kod žena u postmenopauzi. Povećanje ITMza1 $\mathrm{kg} / \mathrm{m} 2$ povećava verovatnoću za pojavu hipertenzije za $24 \%$. Takođe, porast HOMA-IR za 1 jedinicu povećava verovatnoću za pojavu hipertenzije za skoro 2,5 puta. Čak $47 \%$ varijacije u vrednosti krvnog pritiska može biti objašnjeno ovim modelom. Takođe, ovaj model je ispravno klasifikovao $76 \%$ žena u postmenopauzi koje imaju hipertenziju. Zaključak: I gojaznost, i insulinska rezistencija su nezavisni prediktori krvnog pritiska kod žena u postmenopauzi.
\end{abstract}

Ključne reči: hipertenzija, insulinska rezistencija, gojaznost, žene u postmenopauzi

\begin{abstract}
Aim: Although previous studies confirmed the association between obesity and hypertension, the underlying pathophysiological mechanism is not well elucidated, specially considering the fact that discordant results exist when examining the independent role of obesity and/or insulin resistance on risk for hypertension onset. Therefore, we aimed to examine if obesity [as measured with body mass index (BMI)] is a predictor for hypertension, independently of insulin resistance [as measured with Homeostasis model assessment of insulin resistance (HOMA-IR)] in the cohort of postmenopausal women. Methods: A total of 150 postmenopausal women non-treated with medications(among them $44.7 \%$ hypertensive)were included in cross-sectional study. Anthropometric and biochemical parameters, so as blood pressure were obtained. HOMA-IR was calculated. Results: Multivariate logistic regression analysisrevealed that both, BMI and HOMA-IR were the independent predictors of blood pressure in postmenopausal women $(\mathrm{OR}=1.240, \mathrm{p}=0.035$ and $\mathrm{OR}=2.419, \mathrm{p}=0.008$, respectively). Rise in $\mathrm{BMI}$ for 1 $\mathrm{kg} / \mathrm{m} 2$ enhanced the probability for higher blood pressure by $24 \%$. Also, elevation in HOMA-IR for 1 unit, rose the probability for higher blood pressure almost 2.5 times. Even $47 \%$ of variation in blood pressure could be explained with this Model. Also, this Model correctly classified 76\% of postmenopausal women having hypertension. Conclusions: Both, obesity and insulin resistance are the independent predictors of blood pressure in postmenopausal women.

Keywords: hypertension, insulin resistance, obesity, postmenopausal
\end{abstract}

Adresa autora: Aleksandra Klisić, Centar za laboratorijsku dijagnostiku, Dom zdravlja, Trg Nikole Kovačevića 6, 81000 Podgorica, Crna Gora E-mail: aleksandranklisic@gmail.com Rad primljen: 10.10.2017. Elektronska verzija objavljena: 15.01. 2018. www.tmg.org.rs 


\section{INTRODUCTION}

It is well known that women experiencing menopause have unfavorable cardiometabolic profile, compared to women in reproductive age [1]. These changes are mostly attributable to hormonal disturbances, mainly due to loss of estrogen [2]. Therefore, it is not surprising that postmenopausal women had higher incidence of cardiometabolic disorders than premenopausal women $[1,3]$.

It is speculated that redistribution of adipose tissue towards visceral region, due to hormonal changes may be the main pathogenic entity, consequently leading to increased cardiometabolic risk [4] in postmenopause. Increased visceral fat mass is a source of proinflammatory adipocytokines [5-8], exerting a low-grade inflammation environment which could predispose to the future hypertension occurrence [9].

In addition, increased abdominal fat mass is accompanied with increased insulin resistance $[4,8]$. However, even though previous studies confirmed the association between obesity and hypertension, the underlying pathophysiological mechanism is not well elucidated $[10,11]$. Especially considering the fact that discordant results were seen in literature when examining the independent role of obesity and/or insulin resistance on risk for hypertension occurrence and progression. Namely, some studies reported that obesity may be associated with hypertension incidence, acting through some other mechanisms, different from insulin signaling pathways $[10,11]$.

Having this in mind, we aimed to examine if obesity [as measured with body mass index (BMI)] has a predictive role for hypertension, independently of insulin resistance [as measured with Homeostasis model assessment of insulin resistance (HOMA-IR)] in the cohort of postmenopausal women.

\section{Study population \\ MATERIALS AND METHODS}

The current cross-sectional study derived from our previous works investigating the utility of examining cardiometabolic markers in postmenopausal women [1-7].

A total of 150 postmenopausal women nontreated with medications (among them 44.7\% hypertensive) were included in cross-sectional study. All examined women were recruited by the gynecologist in the Center of Laboratory Diagnostics of the Primary Health Care Center in Podgorica, Montenegro, for their regular biochemical analyses check-up in a period from October 2012 to May 2013. Women were considered to be postmenopausal if they reported the absence of menstrual bleeding for more than one year.

Inclusion criteria to enter the study were: menopausal status, no signs and symptoms of acute inflammatory disease, no history of malignancy, non-smoking, and no any medicament therapy usage in the last six months.

Exclusion criteria were: High sensitivity Creactive protein (hsCRP) $>10 \mathrm{mg} / \mathrm{L}$, diabetes mellitus, hypothyroidism or hyperthyroidism, liver disease other than steatosis, renal dysfunction, cardiovascular disorders, and any medications use in the last six months.

All postmenopausal women signed informed consent. The investigation was carried out in compliance with the Declaration of Helsinki, and Ethical Committee of Primary Health Care Center in Podgorica, Montenegro approved the study protocol.

Anthropometric measurements

Basic anthropometric measurements were obtained, as described previously [4].

\section{Biochemical analyses}

Biochemical parameters were measured as described elsewhere [4]. Serum levels of glucose, lipid parameters [e.g., total cholesterol (TC), high density lipoprotein cholesterol (HDL-c), low density lipoprotein cholesterol (LDL-c), triglycerides (TG)], bilirubin, uric acid,creatinine, as well as the activity of aspartat aminotransferase (AST), alanine aminotransferase (ALT) and gamma-glutamyl transferase (GGT), were measured spectrophotometrically (Roche Cobas 400, Mannheim, Germany).

Levels of hsCRP were determined using an immunonephelometric assay (Behring Nephelometer Analyzer, BN II, Marburg, Germany). HOMA-IR was calculated, as described elsewhere [2]. Blood pressure was measured and Glomerular filtration rate was estimated (eGFR) as described previously [2, 3]. Hypertension was defined as (systolic/diastolic blood pressure (BP) ( $\geq 140 / \geq 90 \mathrm{mmHg}$ ) [9].

Statistical analysis

Statistical data of the study populations are presented as mean \pm standard deviation for 
normally distributed data, as geometric means (95\% confidence interval - CI) for log-normally distributed data [12] and as median (interquartile range) for skewed distributed data. Distribution of data were tested by Kolmogorov-Smirnov statistical test. Comparisons of continuous normally and lognormally distributed variables were performed using the Student's t-test. Comparisons of skewed distributed data were performed using Mann-Whitney U-test. Spearman's correlation analysis was employed to estimate possible associations of SBP and DBP with general and clinical parameters. Binary logistic regression analysis was performed to assess the ability of demographic and clinical parameters to predict hypertension in postmenopausal women. Postmenopausal women with arterial tension defined as SBP $\geq 140 \mathrm{mmHg}$ and DBP $\geq 90 \mathrm{mmHg}$ were coded as 1 and postmenopausal women with arterial tension defined as SBP $<140 \mathrm{mmHg}$ and DBP $<90 \mathrm{mmHg}$ were coded as 0 . Multivariate logistic regression was performed for Model taking into account all parameters (predictors) that showed significant Spearman bivariate correlation with SBP and DBP. In Model odds (OR) and 95\% CI were determined for each parameter. The explained variation in blood pressurewas given by Nagelkerke R2 coefficient of logistic regression analysis. Receiver operating characteristic (ROC) curve analysis for Model was performed to assess the ability of tested parameters to discriminate menopausal women with or without hypertension. Hosmer-Lemeshow rule for logistic models was used to test if there was a linear relationship between the predictor variables and the log-odds of the criterion variable (blood pressure level). The areas under the curve (AUC) were defined as poor $(0.5 \leq$ AUC $<0.7)$, satisfactory $(0.7 \leq$ AUC $<0.8)$, good $(0.8 \leq$ AUC $<0.9$ ) and excellent (AUC $\geq 0.9$ ) [13]. All statistical analyses were performed using PASW Statistics Version 18.0 and MedCalc version 15.8. All statistical tests were considered when probability level was less than 0.05 .

\section{Results}

The general demographic characteristics of the two study populations are given in Table 1. There were statistical significant differences in all parameters except for menopause duration. Hypertensive menopausal women were older, had higher BMI, WC, SBP and DBP than normotensive menopausal women.

Table 1. General and clinical characteristics of postmenopausal women according to blood pressure Tabela 1. Opšte i kliničke karakteristike ispitivanih žena u postmenopauzi podeljenih na osnovu vrednosti krvnog pritiska

\begin{tabular}{|l|c|c|r|}
\hline & Normotensive & Hypertensive & $\mathrm{p}$ \\
\hline $\mathrm{N}$ & 83 & 67 & \\
\hline Age, years & $55.87 \pm 4.79$ & $57.55 \pm 4.76$ & 0.033 \\
\hline BMI, kg/m2 & $24.75 \pm 3.64$ & $28.58 \pm 4.19$ & $<0.001$ \\
\hline WC, cm ${ }^{*}$ & $85.00(78.00-91.00)$ & $97.00(85.00-103.00)$ & $<0.001$ \\
\hline SBP, mmHg & $110 \pm 17$ & $150 \pm 13$ & 0.005 \\
\hline DBP, mmHg & $75 \pm 10$ & $96 \pm 8$ & 0.001 \\
\hline Menopausal duration, years & $5.55 \pm 4.81$ & $6.49 \pm 4.66$ & 0.230 \\
\hline
\end{tabular}

Data are presented as arithmetic mean \pm SD and compared with Student's t-test.

*Data are presented as median (interquartile range) and compared by Mann-Whitney U test BMI-Body mass index; WC-Waist circumference; SBP-Systolic blood pressure; DBP-Diastolic blood pressure

A significantly higher concentration of TC, LDL-C, TG, glucose, insulin, HOMA-IR, creatinine, uric acid and hsCRP were evident in the group of hypertensive than in normotensive postmenopausal women. On the contrary, HDL-c concentration and eGFR were significantly lower in hypertensive postmenopausal women. There were no significant differences between normotensive and hypertensive women when AST, ALT, ALP and GGT activities, total bilirubin and fibrinogen concentrations were compared between tested groups (Table 2). 
Table 2. Laboratory and clinical parameters of studied postmenopausal women

Tabela 2. Laboratorijski i klinički parametri ispitivanih žena u postmenopauzi

\begin{tabular}{|c|c|c|c|}
\hline & Normotensive & Hypertensive & $\mathrm{P}$ \\
\hline $\mathrm{TC}, \mathrm{mmol} / \mathrm{L}$ & $6.29 \pm 1.02$ & $6.69 \pm 1.06$ & 0.020 \\
\hline HDL-c, mmol/L & $1.80 \pm 0.44$ & $1.56 \pm 0.35$ & $<0.001$ \\
\hline LDL-c, $\mathrm{mmol} / \mathrm{L}$ & $4.05 \pm 0.97$ & $4.62 \pm 1.01$ & 0.001 \\
\hline $\mathrm{TG}, \mathrm{mmol} / \mathrm{L}^{*}$ & $1.14(1.04-1.26)$ & $1.50(1.36-1.67)$ & $<0.001$ \\
\hline Glucose, $\mathrm{mmol} / \mathrm{L}^{* *}$ & $5.20(4.92-5.47)$ & $5.40(5.10-5.97)$ & 0.005 \\
\hline Insulin, $\mu \mathrm{IU} / \mathrm{L}^{*}$ & $5.21(4.73-5.75)$ & $8.28(7.38-9.30)$ & $<0.001$ \\
\hline HOMA-IR* & $1.21(1.09-1.34)$ & $2.01(1.78-2.28)$ & $<0.001$ \\
\hline $\mathrm{AST}, \mathrm{U} / \mathrm{L}^{* *}$ & $18(17-22)$ & $17(15-19)$ & 0.100 \\
\hline ALT, U/L** & $18(14-22)$ & $18(14-24)$ & 0.647 \\
\hline GGT, U/L** & $11(9-15)$ & $12(9-16)$ & 0.307 \\
\hline Total bilirubin, $\mu \mathrm{mol} / \mathrm{L}^{* *}$ & $7.9(6.3-11.00)$ & $7.30(6.82-7.70)$ & 0.124 \\
\hline Creatinine, $\mu \mathrm{mol} / \mathrm{L}^{* *}$ & $54.00(48.25-59.00)$ & $58.00(50.25-62.75)$ & 0.038 \\
\hline eGFR, $\mathrm{mL} / \mathrm{min} / 1.73 \mathrm{~m}^{2}$ & $102.53 \pm 7.97$ & $98.96 \pm 6.58$ & 0.004 \\
\hline Uric acid, $\mu \mathrm{mol} / \mathrm{L}$ & $242.11 \pm 58.79$ & $286.75 \pm 63.57$ & $<0.001$ \\
\hline HsCRP, mg/L* & $0.79(0.63-0.98)$ & $1.30(1.03-1.65)$ & 0.002 \\
\hline Fibrinogen, $\mathrm{g} / \mathrm{L}^{* *}$ & $3.60(3.40-4.17)$ & $3.90(3.42-4.40)$ & 0.127 \\
\hline $\begin{array}{l}\text { Data are presented as al } \\
\text { compared with Student' } \\
\text { *Log-normal distributed } \\
\text { geometric mean }(95 \%\end{array}$ & $\begin{array}{l}\text { nean } \pm \text { SD and } \\
\text { presented as } \\
\text { ompared with }\end{array}$ & \multicolumn{2}{|c|}{$\begin{array}{lr}\text { aminotransferase; } & \text { ALT-Alanine } \\
\text { aminotransferase; } & \text { GGT-Gamma-glutamil } \\
\text { transferase; eGFR-Estimated glomerular } \\
\text { filtration rate; hSCRP-High-sensitivity C-reactive } \\
\text { protein }\end{array}$} \\
\hline
\end{tabular}

Student's t-test after logarithmic transformation

** Skewed distributed data are presented as median (interquartile range) and compared with Mann-Whitney U test

TC-Total cholesterol; HDL-c-High density lipoprotein cholesterol; LDL-c-Low density lipoprotein cholesterol; TG-Triglycerides; HOMA-IR-Homeostasis model assessment of insulin resistance; AST-Aspartat
According to Spearman's non-parametric correlation analysis significant positive correlations were determined between both, SBP and DBP, with age, BMI, WC, TC, LDL-c, TG, glucose, insulin, HOMA-IR, uric acid and hsCRP (Table 3). Significant negative correlations were determined between both, SBP and DBP, and HDL-c, AST and eGFR.

Table 3. Associations between SBP, DBP and other clinical parameters

Tabela 3. Povezanost između sistolnog, dijastolnog krvnog pritiska i kliničkih parametara

\begin{tabular}{|l|r|r|r|r|}
\hline \multirow{2}{*}{} & \multicolumn{2}{|c|}{ SBP, mmHg } & \multicolumn{2}{c|}{ DBP, mmHg } \\
\cline { 2 - 5 } & \multicolumn{1}{|c|}{$\rho$} & \multicolumn{1}{c|}{$\mathrm{p}$} & \multicolumn{1}{c|}{$\rho$} & \multicolumn{1}{c|}{$\mathrm{p}$} \\
\hline Age, years & 0.215 & 0.008 & 0.266 & 0.001 \\
\hline BMI, kg/m2 & 0.467 & $<0.001$ & 0.437 & $<0.001$ \\
\hline WC, cm & 0.465 & $<0.001$ & 0.423 & $<0.001$ \\
\hline Menopause duration, years & 0.144 & 0.080 & 0.132 & 0.095 \\
\hline TC, mmol/L & 0.195 & 0.017 & 0.354 & $<0.001$ \\
\hline HDL-c, mmol/L & -0.354 & $<0.001$ & -0.363 & $<0.001$ \\
\hline LDL-c, mmol/L & 0.345 & $<0.001$ & 0.357 & $<0.001$ \\
\hline TG, mmol/L & 0.385 & $<0.001$ & 0.369 & $<0.001$ \\
\hline Glucose, mmol/L & 0.314 & $<0.001$ & 0.279 & 0.001 \\
\hline
\end{tabular}




\begin{tabular}{|l|r|r|r|r|}
\hline Insulin, $\mu \mathrm{IU} / \mathrm{L}$ & 0.519 & $<0.001$ & 0.482 & $<0.001$ \\
\hline HOMA-IR & 0.535 & $<0.001$ & 0.504 & $<0.001$ \\
\hline AST, U/L & -0.237 & 0.003 & -0.197 & 0.016 \\
\hline ALT, U/L & 0.075 & 0.363 & 0.043 & 0.606 \\
\hline GGT, U/L & 0.143 & 0.080 & 0.092 & 0.263 \\
\hline Total bilirubin, $\mu \mathrm{mol} / \mathrm{L}$ & -0.151 & 0.066 & -0.143 & 0.081 \\
\hline Creatinine, $\mu \mathrm{mol} / \mathrm{L}$ & 0.156 & 0.056 & 0.153 & 0.061 \\
\hline eGFR, mL/min/1.73m ${ }^{2}$ & -0.259 & 0.001 & -0.267 & 0.001 \\
\hline Uric acid, $\mu \mathrm{mol} / \mathrm{L}$ & 0.383 & $<0.001$ & 0.362 & $<0.001$ \\
\hline HsCRP, mg/L & 0.284 & $<0.001$ & 0.232 & 0.004 \\
\hline Fibrinogen, g/L & 0.125 & 0.129 & 0.097 & 0.236 \\
\hline
\end{tabular}

$\rho$ - Spearman's correlation coefficient

BMI-Body mass index; WC-Waist circumference; TC-Total cholesterol; HDL-c-High density lipoprotein cholesterol; LDL-c-Low density lipoprotein cholesterol; TG-Triglycerides; HOMA-IR-Homeostasis model assessment of insulin resistance; AST-Aspartat aminotransferase; ALT-Alanine aminotransferase; GGTGamma-glutamil transferase; eGFR-Estimated glomerular filtration rate; hsCRP-High-sensitivity Creactive protein

Multivariate logistic regression analysis was used to establish the independent associations of blood pressure and tested parameters which showed significant correlations with SBP and DBP (Table 4). Those predictors were age, BMI, WC, TC, HDL-c, LDL-c, TG, HOMA-IR, AST, eGFR, uric acid, and hsCRP.Hosmer-Lemeshow rule for logistic models showed that there was a linear relationship between the predictor variables and the log-odds of the blood pressure levels (Chisquared value was $8.200, \mathrm{p}=0.414$ ). Although, glucose and insulin concentrations showed significant correlations with SBP and DBP, they were excluded from multivariate logistic regression analysis because they entered equation for HOMA-IR calculation. Adjusted ORs for tested parameters were shown in Table 4 . BMI and HOMA-IR were shown to be the independent predictors of blood pressure in postmenopausal women $(\mathrm{OR}=1.240, \mathrm{p}=0.035$ and $\mathrm{OR}=2.419, \mathrm{p}=0.008$, respectively). Rise in BMI for $1 \mathrm{~kg} / \mathrm{m} 2$ enhanced the probability for higher blood pressure by $24 \%$. Also, elevation in HOMA-IR for 1 unit, rose the probability for higher blood pressure almost 2.5 times. Adjusted Nagelkerke R2 coefficient for the Model was 0.470 , which means that $47 \%$ of variation in blood pressure could be explained with this Model. Also, this Model correctly classified 76\% of postmenopausal women having hypertension.

Table 4. Odds ratios (OR) after multivariate logistic regression analysis for parameters predicting abilities towards blood pressure

Tabela 4. Statistička verovatnoća nakon multivarijantne logističke regresione analize za predikciju krvnog pritiska

\begin{tabular}{|l|l|l|}
\hline Predictors & $\begin{array}{l}\text { Adjusted } \\
\text { OR }(95 \% \mathrm{CI})\end{array}$ & $\mathrm{p}$ \\
\hline Age, years & $1.224(1.025-1.461)$ & 0.102 \\
\hline BMI, kg/m2 & $1.240(1.015-1.515)$ & 0.035 \\
\hline $\mathrm{WC}, \mathrm{cm}$ & $0.922(0.851-1.012)$ & 0.080 \\
\hline TC, $\mathrm{mmol} / \mathrm{L}$ & $0.543(0.099-2.981)$ & 0.483 \\
\hline
\end{tabular}




\begin{tabular}{|l|l|l|}
\hline HDL-c, mmol/L & $0.525(0.069-3.995)$ & 0.534 \\
\hline LDL-c, mmol/L & $2.707(0.489-14.991)$ & 0.254 \\
\hline TG, mmol/L & $1.175(0.463-2.980)$ & 0.753 \\
\hline HOMA-IR & $2.419(1.266-4.623)$ & 0.008 \\
\hline AST, U/L & $0.865(0.700-1.095)$ & 0.275 \\
\hline eGFR,mL/min/1.73m ${ }^{2}$ & $1.014(0.942-1.091)$ & 0.716 \\
\hline Uric acid, $\mu \mathrm{mol} / \mathrm{L}$ & $1.008(0.999-1.017)$ & 0.072 \\
\hline HsCRP, mg/L & $1.136(0.861-1.500)$ & 0.367 \\
\hline
\end{tabular}

BMI-Body mass index; WC-Waist circumference; TC-Total cholesterol; HDL-c-High density lipoprotein cholesterol; LDL-c-Low density lipoprotein cholesterol; TG-Triglycerides; HOMA-IR-Homeostasis model assessment of insulin resistance; AST-Aspartate aminotransferase; eGFR-Estimated glomerular filtration rate; hsCRP-High-sensitivity C-reactive protein

ROC analysis was used to discriminate postmenopausal women with hypertension from normotensive ones. When the Model tested in multivariate logistic regression analysis was used in ROC analysis, the clinical accuracy for diagnostic procedure was good (AUC=0.853; 95\%CI 0.787-0.906; SE=0.030). As well, this diagnostic procedure had sensitivity of $83.6 \%$ and specificity of $74.7 \%$ (Figure 1 ).

Figure 1. ROC curve of Model discriminating ability between normotensive and hypertensive postmenopausal women

Slika 1. ROC kriva Modela za sposobnost diskriminacije između normotenzivnih i hipertenzivnih žena u postmenopauzi

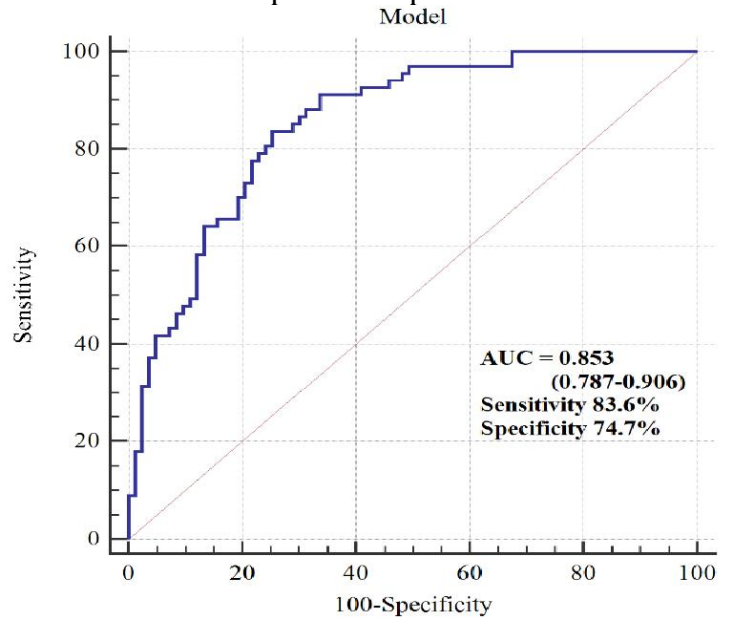

\section{Discussion}

Our study demonstrated that non-treated hypertensive postmenopausal women had higher anthropometric indices (Table 1), unfavorable lipid profile and HOMA-IR, as well as higher inflammation level (Table 2) as compared with normotensive counterparts. In addition, those women displayed higher uric acid level and lower level of eGFR (Table 2). However, multivariate logistic regression analysisrevealed that both, BMI and HOMA-IR were the independent predictors of blood pressure in postmenopausal women $(\mathrm{OR}=1.240$, $\mathrm{p}=0.035$ and $\mathrm{OR}=2.419, \mathrm{p}=0.008$, respectively), (Table 4). Rise in BMI for $1 \mathrm{~kg} / \mathrm{m} 2$ enhanced the probability for higher blood pressure by $24 \%$. Also, elevation in HOMA-IR for 1 unit, rose the probability for higher blood pressure almost 2.5 times. In addition, even $47 \%$ of variation in blood pressure could be explained with this Model. Also, this Model correctly classified 76\% of postmenopausal women having hypertension, 
which is of great importance concerning the fact that hypertension is often undiagnosed and untreated, leading to serious health consequences [14].

Furthermore, ROC analysis was used to discriminate postmenopausal women with hypertension from normotensive ones. When the Model tested in multivariate logistic regression analysis was used in ROC analysis, the clinical accuracy for diagnostic procedure was good (AUC=0.853). As well, this diagnostic procedure had sensitivity of $83.6 \%$ and specificity of $74.7 \%$ (Figure 1).

Contradictory research results were observed when examining the independent role of obesity and/or insulin resistance on risk for hypertension. Namely, some studies reported independent relationship between obesity and hypertension incidence, acting through some other mechanisms, different from insulin signaling pathways $[10,11]$. In line with this, Faria et al. [10] demonstrated the association between visceral fat and blood pressure, whereas No relationship between blood pressure levels and HOMA-IR was shown. Similar results were obtained from the study conducted by Lytsy et al. [15] in the cohort of middle-aged and elderly men, confirming that overweight/obesity without insulin resistance increases the risk of hypertension.

On the other hand, our results are similar with the results of Ben Ali et al. [11], which reported the independent influence of both obesity and HOMA-IR on blood pressure in postmenopausal women.

Insulin resistance as the link between obesity and hypertension is well established, since hyperinsulinemia may enhance sympathetic activity and sodium tubular reabsorption $[8,16]$. However, some other mechanisms, different from insulin signaling pathways have been also proposed to cause hypertension development $[17,18]$. One possible mechanism lays in the explanation that sodium retention may result from disturbances in the kidney tissue, due to a compressive effect of the enlarged visceral fat [19]. This further results in an hyperactivity of the renin angiotensin system and consequent increase in sodium reabsorption. This hypothesis is further supported by some studies which demonstrated a significant relationship between the amount of visceral fat and systolic blood pressure [10].
Furthermore, some studies suggest that the presence of a low-grade inflammation could predict the future onset of hypertension [9]. Lukic et al. [9] showed that increases in inflammation might be an important factor influencing the occurrence of hypertension in obese patients with diabetes, but which was associated with the rise in interleukin-6 (IL-6). Another pathogenic mechanism of hypertension onset may be attributed to the role of arterial stiffening which precedes the hypertension occurrence [20]. In this regard, it was suggested that low-grade inflammation may contribute to arterial stiffness, since the impairments in pulse wave velocity, a measure of large vessels distension ability, were correlated with the increases in circulating levels of IL- 6 and tumor necrosis factor (TNF)- $\alpha[21,22]$. Furthermore, there are assumptions that pro-inflammatory cytokines may exert a direct pathogenic influence on vascular tone regulation leading to the hypertension development [23].

In our study, hypertensive postmenopausal women displayed higher level of inflammation (as measured with hsCRP), and it correlated well with both systolic and diastolic blood pressure in Spearman's non-parametric correlation analysis (Table 3). However, this association was dependent on both, BMI and HOMA-IR in our study (Table 4).

Indeed, exogenous administration of TNF- $\alpha$ or IL-6 resulted in enhanced insulin resistance, suggesting that many cytokines may act in synchrony manner to induce this process [23]. In addition, enlarged adipose tissues is significant contributor of increased pro-inflammatory cytokines in circulation $[4,5,8]$, thus further leading to decreased insulin sensitivity.

A small sample size and cross-sectional design are some limitations of our study. However, our cohort comprised of normotensive and nontreated hypertensive postmenopausal women, so we excluded medicines as confounding factors when estimating cardiometabolic profile of hypertensive group. Future longitudinal studies are needed to further explore patophysiological mechanisms related to hypertension onset and to find the best therapeutic target approach for its complications. 


\section{Conclusion}

Non-treated hypertensive postmenopausal women exerted unfavorable cardiometabolic profile, compared to normotensive counterparts. Both, body mass index and insulin resistance were the independent predictors of blood pressure in postmenopausal women.

\section{REFERENCES}

1. Jovanović M, Klisić A, Kavarić N, Škerović V. Prevalence of metabolic syndrome among postmenopausal women in Montenegro-relation to hyperuricemia. Timoč med glas 2016; 41(3): 196-202.

2. Klisic A, Kotur-Stevuljevic J, Kavaric N, Martinovic M, Matic M. The association between follicle stimulating hormone and glutathione peroxidase activity is dependent on abdominal obesity in postmenopausal women. Eat Weight Disord - St DOI: 10.1007/s40519016-0325-1.

3. Klisic A, Kotur-Stevuljevic J, Kavaric N, Matic M. Relationship between cystatin $\mathrm{C}$, retinol-binding protein 4 and Framingham risk score in healthy postmenopausal women. Arch Iran Med 2016; 19(12): 845-851.

4. Klisic A, Kavaric N, Jovanovic M, Soldatovic I, GligorovicBarhanovic N, Kotur-Stevuljevic J. Bioavailable testosterone is independently associated with fatty liver index in postmenopausal women. Arch Med Sci 2017; 5 (13): 1188-1196.

5. Klisic AN, Vasiljevic ND, Simic TP, Djukic TI, Maksimovic MZ, Matic MG. Association between C-reactive protein anthropometric and lipid parameters among healthy normal weight and overweight postmenopausal women in Montenegro. Lab Med 2014; 45(1): 12-16.

6. Klisić A,Kotur-Stevuljević J, Kavarić N, Jovanović M, Škerović V. Correlation between fibrinogen level and cardiometabolic risk factors in overweight/obese postmenopausal women. Timoč med glas 2016; 41(2): 83-90.

7. Klisić A, Kotur-Stevuljević J, Kavarić N, Jovanović M. The influence of obesity on serum uric acid level in postmenopausal women. Timoč med glas 2016; 41(1): 20-26.

8. Klisić A, Jovanović M, Kavarić N, Škerović V. Retinol vezujući protein 4 i hiperinsulinemija kao veza između gojaznosti i kardiovaskularnih bolesti. Timoč med glas 2017; 42 (1): 42-47.

9. Lukic L, Lalic NM, Rajkovic N, Jotic A, Lalic K, Milicic T, et al. Hypertension in obese type 2 diabetes patients is associated with increases in insulin resistance and IL-6 cytokine levels: potential targets for an efficient preventive intervention. Int J Environ Res Public Health 2014;11(4):3586-3598.

10. Faria AN, Ribeiro Filho FF, Gouveia Ferreira SR, Zanella MT. Impact of visceral fat on blood pressure and insulin sensitivity in hypertensive obese women. Obes Res 2002;10(12):1203-1206.

11. Ben Ali S, Belfki-Benali H, Ahmed DB, Haddad N, Jmal A, Abdennebi $M$, et al. Postmenopausal hypertension, abdominal obesity, apolipoprotein and insulin resistance. Clin Exp Hypertens 2016;38(4):370-374.

12. Bland JM, Altman DG. Transformations, means and confidence intervals. BMJ 1996;312:1079.

13. Swets JA. Measuring the accuracy of diagnostic systems. Science 1988; 240:1285-1293.
Acknowledgement

This work was financially supported in part by a grant from the Ministry of Education, Science and Technological Development, Republic of Serbia (Project number 175035).

Conflict of Interest Statement

The authors declared no conflicts of interest.

14. Wang W, Lee ET, Fabsitz RR, Devereux R, Best L, Welty TK, et al. A longitudinal study of hypertension risk factors and their relation to cardiovascular disease: the Strong Heart Study. Hypertension 2006;47(3):403-409.

15. Lytsy $\mathrm{P}$, Ingelsson $\mathrm{E}$, Lind L, Arnlöv J, Sundström J. Interplay of overweight and insulin resistance on hypertension development. J Hypertens 2014;32(4):834849.

16. Berne C. Insulin resistance in hypertension-a relationship withconsequences? J Intern Med 1991;229(suppl 2):65-73.

17. Hall JE, Zappe D, Kassab S. Mechanisms of obesity induced hypertension. News Physiol Sci 1996;11:255261.

18. Hall JE, Brands MW, Zappe DH, Alonso-Galicia M. Insulin resistance, hyperinsulinemia and hypertension: causes, consequences or merely correlations? Proc Soc Exp Biol Med 1995;208:317-329.

19. Hall JE. Renal and cardiovascular mechanisms of hypertension in obesity. Hypertension Dallas 1994;23:381-394.

20. Pirro M, Schillaci, G, Savarese G, Gemelli F, Mannarino MR, Siepi D, et al. Attenuation of inflammation with short-term dietary intervention is associated witha reduction of arterial stiffness in subjects with hypercholesterolaemia. Eur J Cardiovasc PrevRehabil 2004; 11: 497-502.

21. Egan BM. Insulin resistance and sympathetic nervous system. Curr Hypertens Rep 2003; 5: 247-254.

22. Frontoni S, Bracaglia D, Gigli F. Relationship between autonomic dysfunction, insulinresistance and hypertension, in diabetes. Nutr Metab Cardiovasc Dis 2005; 15: 441-449.

23. Badawi A, Klip A, Haddad P, Cole DEC, Garcia Bailo B, ElSohemy A, et al. Type 2 diabetes mellitus and inflammation: Prospects for biomarkers of risk and nutritional intervention. Diabetes Metab Syndr Obes 2010;3:173-186. 